\title{
A CONSTRUÇÃO DO ETHOS INDÍGENA PELAS VOZES LITERÁRIAS ETHOS' CONSTRUCTION BY INDIGINOUS LITERARY VOICES
}

\author{
Célia Zeri de OLIVEIRA \\ Universidade Federal do Pará - UFPA \\ UFPA/ILC/FALE \\ celia.zeri@gmail.com
}

\begin{abstract}
RESUMO: Neste artigo, buscamos analisar por meio do viés do discurso na perspectiva enunciativa, a construção do ethos discursivo de um personagem que é parte constituinte da nação brasileira, isto é, os povos indígenas. Tomamos como corpora os textos literários produzidos no decorrer do processo de formação da nação brasileira e, assim, da literatura nacional. 0 corpus estudado são os textos literários que expressam o ethos do indígena, realizado por meio de análise da construção das imagens discursivas, conformadas por meio da representação literária em que a voz desse ator social é tomada pela representação que se faz dela em caráter de reconstrução da história por linhas literárias. A base teórica que sustenta as análises interpretativas insere-se na linha do discurso em que os processos de discursivização são utilizados para a compreensão de imagens discursivas que têm por objetivo criar um tipo de mentalidade social, nesse contexto, construída ideologicamente por meio dos gêneros literários.
\end{abstract}

Palavras-chave: Ethos, Formação Discursiva, Literatura Indígena.

ABSTRACT: This article aims to analyze, through the bias of discourse in the enunciative perspective, the construction of the discursive ethos of a people that is a constituent part of the Brazilian nation, that are, the indigenous peoples. We take as corpora the literary texts produced during the process of formation of the Brazilian nation and, thus, of the national literature. So, our corpus of study are the literary texts that express the ethos of the indigenous, this was done by the analysis of the construction of the discursive images conformed as the literary representation in which the voice of this social actor is taken by the representation that is made as the reconstruction of history by literary lines. The theoretical basis that supports the interpretative analyzes is inserted in the line of discourse in which the processes of transformation in discourse are used for the understanding of discursive images that aim to create a type of social mentality, in this context, constructed ideologically through the literary genres .

Key-words: Ethos, Discursive Formation, Indigenous Literature.

A vontade de verdade, que ainda nos seduzirá a muitas ousadias, essa célebre veracidade, da qual todos os filósofos até agora falara com veneração: que questões essa vontade de verdade nos colocou!

(Nietzche, [1900] 2008).

\section{Palavras iniciais}

Há tempos, temos passado por uma variedade de conceitos acerca das funções da literatura no âmbito da formação e desenvolvimento das sociedades, dentre elas, o uso da linguagem de forma aperfeiçoada, artística e bela, com as metas de recriar a realidade pelo viés artístico, como forma de reconstrução da 
própria história dos povos e civilizações, sobretudo, como a arte do registro das culturas através do tempo num espaço determinado que reproduz ou recria o contexto. Entretanto, mais do que as funções literárias propostas por António Cândido (1989) sobre a função humanizadora da literatura, sobretudo a possibilidade que lhe dá a magia de confirmar a humanidade do ser humano, queremos nos referir, neste artigo, às ações da literatura no que se refere à criação e manutenção dos ethe no sentido discursivo, peculiarmente de um grupo de pessoas em específico e importantíssimo na construção e constituição da nação brasileira, os indígenas das várias etnias presentes no início da colonização portuguesa nessa parte da América até os dias atuais, como parte integrante da nação brasileira.

Desse modo, fazemos um estudo discursivo ligado à própria enunciação valendo-nos da base teórica construída por meio dos escritos de Maingueneau por uma perspectiva de análise discursiva (1997, 2008, 2013, 2015) em que, a princípio, discute as características em relação ao ethos proposto por Aristóteles no que se refere à retórica que consistia em causar boa impressão pela forma na qual se constrói o discurso, ou para dar uma imagem de si capaz de convencer o auditório por meio do ganho da confiança, usando certas propriedades às instâncias postas como fonte de acontecimento enunciativo; entretanto, o autor chega ao conceito de ethos atual, ou seja, o viés discursivo em que se insere a argumentação. Nesse caso, o conceito de ethos que adotamos está vinculado à noção discursiva, isto é, à construção que se faz dele através do discurso, fundamentalmente sob um processo interativo de influência sobre o outro, tendo como princípio uma função, fundamentalmente híbrida (sociodiscursiva), por meio de um comportamento socialmente avaliado e que não é possível ser apreendido de modo externo à situação de comunicação precisa, quer dizer, só pode ser compreendida se integrada numa conjuntura sócio-histórica.

Nessa perspectiva, de acordo com Maingueneau (2015), o ethos elabora-se por meio de uma percepção complexa e mobilizadora da afetividade do intérprete, o qual retira as informações para essa construção por meio do material linguístico e do ambiente. Todavia, o agravamento disso deve-se ao fato de que o ethos é um efeito do discurso, supondo-se, assim, que se pode delimitar o que decorre do 
discurso. Além disso, há outros elementos que podem influenciar o ato da comunicação, mesmo sendo difícil definir se fazem ou não parte do discurso, tais como as roupas do locutor, os gestos, a proximidade, ou seja, o quadro geral da comunicação, transformando esse processo em algo sutil e delicado, pois o próprio ethos articula elementos verbais e não verbais, provocando efeitos multissensoriais.

A literatura, ou a criação literária, nessa concepção discursiva, ao longo do tempo, na linha de periodização da literatura brasileira, paulatinamente, criou o ethos de uma personagem, isto é, a figura do indígena, que mistura o artístico ao real na forma citada por Todorov (2009) em que a literatura fala apenas de si mesma e a única forma de honrá-la é valorizar o jogo de seus elementos constitutivos que, per si, cultivam a construção engenhosa, quer dizer, os processos mecânicos de engendramento do texto, as simetrias, os ecos e os pequenos sinais cúmplices, ou, de outro modo, encara uma visão de mundo que pode ser classificada de niilista, segundo a qual a concepção literária traduz a verdadeira condição humana como um advento de um desastre natural e permanente. De acordo com Todorov (2009, p.42) "não se pode afirmar que a literatura não descreve o mundo, mais do que uma negação da representação, ela é uma a representação de uma negação".

Desse modo, no decorrer das formações das escolas literárias na literatura brasileira, os autores que vão, desde o Quinhentismo à literatura contemporânea, representam um ethos indígena criado dentro dos seus ideais de ser, quer dizer, mitificando o que deveria ser a imagem de um povo constituinte da nação brasileira por meio de muitas representações sociais, a princípio, do habitante ingênuo e não civilizado que poderia ser alvo de trocas de interesses da coroa portuguesa. No barroco, representam aquele a quem outros deveriam proteger por não apresentarem uma cultura que destacasse traços de desenvolvimento humano; no romantismo, a figura do bom guerreiro que luta por sua sobrevivência, entretanto dócil e passível de domesticação, até que no último século, isto é, no século XXI temos o despontar de autores contemporâneos que se autorrepresentam, tomando para si o direito de constituírem-se discursivamente. 


\section{A construção discursiva do ethos indígena no decorrer dos períodos literários}

Ao tratarmos da construção das identidades de um grupo social, é importante refletir acerca das construções sociais e culturais, sobretudo porque nas nossas sociedades passamos por várias questões dessa formação, que podem enquadrar-se nos âmbitos da sociologia, da antropologia, da psicologia, da história, e, no caso específico dessa análise, da construção do ethos identitário pelo viés da literatura. De acordo com Cosson (2018, p.16) "todas as transações humanas de nossa sociedade passam, de uma maneira ou de outra, pela escrita, mesmo aquelas que, aparentemente, são orais ou imagéticas". E assim, as palavras são provenientes da sociedade, da qual fazemos parte; são de todos e de ninguém, por isso, simultaneamente, pelo uso individual e coletivo, que se modificam, dividemse e multiplicam-se, vestindo de sentido o fazer humano.

Desse modo, a linguagem ocupa papel central no contexto das ciências sociais, pois está no cerne da construção do sujeito, de modo individual ou coletivo, de acordo com Charaudeau (2015, p.13) em três domínios da atividade humana:

- 0 domínio da socialização dos indivíduos, na medida em que é através da linguagem que se instaura a relação de si com o outro e que se cria o elo social;

- 0 domínio do pensamento, na medida em que é pela linguagem que conceituamos e extraímos o mundo de sua realidade empírica para fazêlo significar.

- O domínio dos valores, na medida em que estes precisam ser ditos para existir.

A linguagem, nesses aspectos, atribui certa liberdade ao indivíduo como possibilidade de análise sobre si e sobre o outro, trazendo para as discussões a criação das identidades individuais ou coletivas, tais como: quem julga a identidade de alguém? A identidade é individual ou coletiva, a identidade resulta da natureza ou da cultura? Talvez dessas questões, podemos concluir que a criação de identidades tem causado mais aprisionamento de indivíduos do que liberdade, como o exemplo das identidades criadas para os povos indígenas por meio de conceitos identitários através da literatura. Em princípio, no Quinhentismo, produz-se a figura do habitante ingênuo e disposto a conhecer os colonizadores; no Barroco, a identidade doce e cortês dos habitantes étnicos, no Romantismo, a 
figura do herói belo e bom, até que se rompem os tempos contemporâneos em que se tem a desmitificação do indígena brasileiro. No excerto a seguir, da carta de Pero Vaz de Caminha, buscamos compreendê-lo pela voz do outro, quer dizer, as representações sociais partilhadas, como estereótipos, preconceitos e ideologias que reproduzem no dia a dia a participação de diversos grupos por meio do discurso (Van Dijk, 2000).

Desse modo, os enunciados decorrentes dessas formações discursivas decorrem de algum tipo de "mentalidade" criada social e ideologicamente que, em graus e uso de estratégias diversas, regeria conceitos e pensamentos constituídos por motivações amplamente inconfessáveis. Os textos, nesse caso, os literários, seriam movidos por um desejo inconfessado de preservar e legitimar a dominação dos colonizadores aos colonizados (Mainguenaeu, 2015).

\subsection{0 ethos ingênuo e passivo na Carta de Achamento do Brasil por Pero Vaz de Caminha}

Quinta-feira, 23 de abril: Mandou lançar o prumo. Acharam vinte e cinco braças: e, ao sol posto, obra de seis léguas da terra, surgimos âncoras, em dezenove braças - ancoragem limpa. Ali permanecemos toda aquela noite. E à quinta-feira, pela manhã, fizemos vela e seguimos direitos à terra, indo os navios pequenos diante, por dezessete, dezesseis, quinze, quatorze, treze, doze, dez e nove braças, até meia légua da terra, onde todos lançamos âncoras em frente à boca de um rio. E chegaríamos a esta ancoragem às dez horas pouco mais ou menos.

Dalí avistamos homens que andavam pela praia, obra de sete ou oito, segundo disseram os navios pequenos, por chegarem primeiro. Então lançamos fora os batéis e esquifes; e vieram logo todos os capitães das naus a esta nau do capitão-mor, onde falaram entre si. E o capitão-mor mandou em terra no batel a Nicolau Coelho para ver aquele rio. E tanto que ele começou de ir para lá, acudiram pela praia homens, quando aos dois, quando aos três, de maneira que, ao chegar o batel à boca do rio, já ali havia dezoito ou vinte homens....

Eram pardos, todos nus, sem coisa alguma que lhes cobrisse suas vergonhas. Nas mãos traziam arcos com suas setas. Vinham todos rijamente sobre o batel; $e$ Nicolau Coelho lhes fez sinal que pousassem os arcos. E eles os pousaram. ...

[...]

Ali não pôde deles haver fala, nem entendimento de proveito, por o mar quebrar na costa. Deu-lhes somente um barrete vermelho e uma carapuça de linha que levava na cabeça e um sombreiro preto. Um deles deu-lhe um sombreiro de penas de ave, compridas, com uma copazinha pequena de penas vermelhas e pardas como de papagaio; e outro lhe deu um ramal grande de continhas brancas, miúdas, que querem parecer de aljôfar, as quais peças creio que o Capitão manda a Vossa Alteza, e com isto se volveu às naus por ser tarde e não poder haver deles mais fala, por 
causa do mar. Na noite seguinte ventou tanto sueste com chuvaceiros que fez caçar as naus, e especialmente a capitania. ${ }^{1}$

Nesse excerto da Carta de Achamento temos um discurso constituinte que se responsabiliza pela gestão e criação das normas de uma coletividade, garantindo o comportamento ideal dos membros da comunidade, delimitando o seu lugar-comum. Trata-se dum modo específico de se situar no interdiscurso, segundo Maingueneau (2008) a enunciação se manifesta como dispositivo de legitimação do espaço de sua própria enunciação, ou seja, a articulação de um texto e uma maneira de se inscrever no universo social. Esse universo é construído pela formação de um ethos em que os povos indígenas são vistos como ingênuos e receptivos, demostrado por meio da frase em que os homens indígenas são compelidos a pousarem seus arcos, mesmo sem conhecerem os novos visitantes que se aproximavam em suas naus, obedecendo-os prontamente. Além disso, na descrição de que estavam nus transfere-se o conceito de que eram selvagens, como animais que não tinham a necessidade de usar vestuário para cobrir suas partes íntimas, isto é, demonstravam subserviência, passividade, e até mesmo inferioridade e precisavam ser domesticados. Na frase em que diz não haver possibilidade de diálogo passa-se a impressão de que não possuíam a faculdade da linguagem, transformando-os em não humanos, quer dizer, não podiam comunicar-se com aqueles a quem consideram a si próprio civilizados e o outro como incivilizados.

Ademais, a voz do discurso é assumida pelos representantes da coroa portuguesa, não por um membro dos povos indígenas, desconsiderando seus pertencimentos a etnias e culturas distintas, demonstrando, assim, que se pode falar pelos indivíduos, representando, inclusive, seus pensamentos, sem análise de suas culturas ou de contexto. 0 locutor, assim, cita a sua adesão ao enunciado como se pertencesse de forma indissociável à comunidade a qual esses enunciados circulariam, supondo-se, pragmaticamente, que ele mesmo e seu alocutário são membros da comunidade em si, isto é, cita aquilo que poderia ser dito por ele $r$ ainda mais amplamente, por todos os membros da comunidade, agindo de maneira plena conforme suposição de pertencimento (MAINGUENEU, 2008).

${ }^{1}$ CAMINHA, Pero Vaz. A carta de Pero Vaz de Caminha. Biblioteca Nacional: RJ 


\subsection{0 ethos aculturado em 0 sermão de Santo Antônio por Pe. Antônio Vieira}

\section{Capítulo I}

Vós, diz Cristo, Senhor nosso, falando com os pregadores, sois o sal da terra: e chama-lhes sal da terra, porque quer que façam na terra o que faz o sal. 0 efeito do sal é impedir a corrupção; mas quando a terra se vê tão corrupta como está a nossa, havendo tantos nela que têm ofício de sal, qual será, ou qual pode ser a causa desta corrupção? (...) Enfim, que havemos de pregar hoje aos peixes? Nunca pior auditório. Ao menos têm os peixes duas boas qualidades de ouvintes: ouvem e não falam. Uma só cousa pudera desconsolar o Pregador, que é serem gente os peixes que se não há de converter. Mas esta dor é tão ordinária, que já pelo costume quase se não sente (...) Suposto isto, para que procedamos com clareza, dividirei, peixes, o vosso sermão em dois pontos: no primeiro louvar-vos-ei as vossas atitudes, no segundo repreendervos-ei os vossos vícios. ${ }^{2}$

\section{Capítulo IV}

Olhai peixes, lá do mar para a terra. Não, não: não é isso o que vos digo. Vós virais os olhos para os matos e para o sertão? Para cá, para cá; para a cidade é que haveis de olhar. Cuidais que só os Tapuias se comem uns aos outros? Muito maior açougue é o de cá, muito mais se comem os Brancos. Vedes vós todo aquele bulir, vedes todo aquele andar, vedes aquele concorrer às praças e cruzar as ruas; vedes aquele subir e descer as calçadas, vedes aquele entrar e sair sem quietação nem sossego? Pois tudo aquilo é andarem buscando os homens como hão de comer e como se hão de comer. Morreu algum deles, vereis logo tantos sobre o miserável a despedaçá-lo e comê-lo. Comem-no os herdeiros, comem-no os testamenteiros, comem-no os legatários, comem-no os acredores; comem-no os oficiais dos órfãos e os dos defuntos e ausentes; come-o o médico, que o curou ou ajudou a morrer; come-o o sangrador que lhe tirou o sangue; come-a a mesma mulher, que de má vontade lhe dá para a mortalha o lençol mais velho da casa; come-o o que lhe abre a cova, o que lhe tange os sinos, e os que, cantando, o levam a enterrar; enfim, ainda o pobre defunto o não comeu a terra, e já o tem comido toda a terra. ${ }^{3}$

A problemática da constituição do ethos do indígena como personalidade histórica, cultural e literária está, justamente, no falar pelo outro, em que a voz do próprio ator social foi desvozeada pelo fato de tirarem-lhes a oportunidade de construir-se por meio do discurso e dos atos sociais. As questões abordadas constituem-se por meio da enunciação, e tudo aquilo que é feito por meio das palavras também pode ser por elas desfeito.

\footnotetext{
2 O sermão de Santo Antônio - Pe. Antônio Vieira (2011, p. 49)

3 O sermão de Santo Antônio - Pe. Antônio Vieira (2011, p. 65)
} 
Authier-Revuz (1998, p. 26) complexifica as relações criadas pelas palavras ao dizer que

\begin{abstract}
essas palavras porosas, carregadas de discursos que elas têm incorporados e pelos quais elas restituem, no coração do sentido do discurso se fazendo, a carga nutriente e destituinte, essas palavras embutidas, que se cindem, se transmutam em outras, palavras caleidoscópicas nas quais o sentido, multiplicado em suas facetas imprevisíveis, afasta-se, ao mesmo tempo, e podem, na vertigem, perder-se, essas palavras que faltam, faltam para dizer, faltam por dizerdefeituosas ou ausentes- [...] Assim é que fundamentalmente, as palavras que dizemos não falam por si, mas pelo... "Outro".
\end{abstract}

Nas palavras bem elaboradas do enunciador Pe. Antônio Vieira, conforme exemplo relatado no sermão acima transcrito, encontramos um ethos do indígena como uma etnia desprovida de elementos históricos, organizacionais e culturais que favorecessem o direito à defesa da forma de ser e de viver socioculturalmente. No capítulo I do Sermão de Santo Antônio, são descritos como explorados, assujeitados ou escravizados pelos colonizadores, sem relatar, nesse excerto literário, qualquer forma de resistência ou posição como agentes, isto é, são passíveis às condições impostas e aceitem-nas sem qualquer oposição ou reação. Ao fazermos a oposição entre a literatura e os estudos antropológicos, encontraríamos muitas marcas de resistência e de não passividade indígena, como exemplos, citamos: a negociação pelas terras e objetos, a comunicação em dialetos pertencentes às várias etnias existentes, o domínio de tecnologias de navegações e das artes de guerra com armas próprias, as fugas por meio do conhecimento geográfico da região, dentre outros. Entretanto, o domínio da linguagem literária é feito pelo alocutário dominador, quer dizer, os colonizadores, que se apoderaram das "palavras porosas" (Authier-Revuz, 1998, p.26) multiplicando os sentidos do dizer e constituindo uma figura imaginária sem mesmo dar oportunidade aos ethos discursivos originais de construir suas corporalidades.

No capítulo IV do Sermão de Santo Antônio, os indígenas são postos pelo literato como aborígenes, o que leva os leitores a incorporar à nação dos Tapuias como bárbaros, selvagens, ou povos que comem uns aos outros, criando, assim, uma comunidade que, de fato, aderiu a esse discurso, numa dimensão ideologia que distancia do conhecimento sobre os rituais de povos distintos que usam artifícios de guerra com objetivos culturais específicos, enraizados como 
patrimônio de suas formas de ser e viver diferentes de outras etnias ou comunidades e, desse modo, vai se construindo o conceito de povo não civilizado ou que não pertence aos conceitos de humanização. Assim, faz- se uma construção sociocultural estereotipada, associada a rituais julgados à revelia do desconhecimento por parte daqueles que se apropriam das palavras.

\subsection{0 ethos do bravo guerreiro em A canção do Tamoio por Gonçalves Dias}

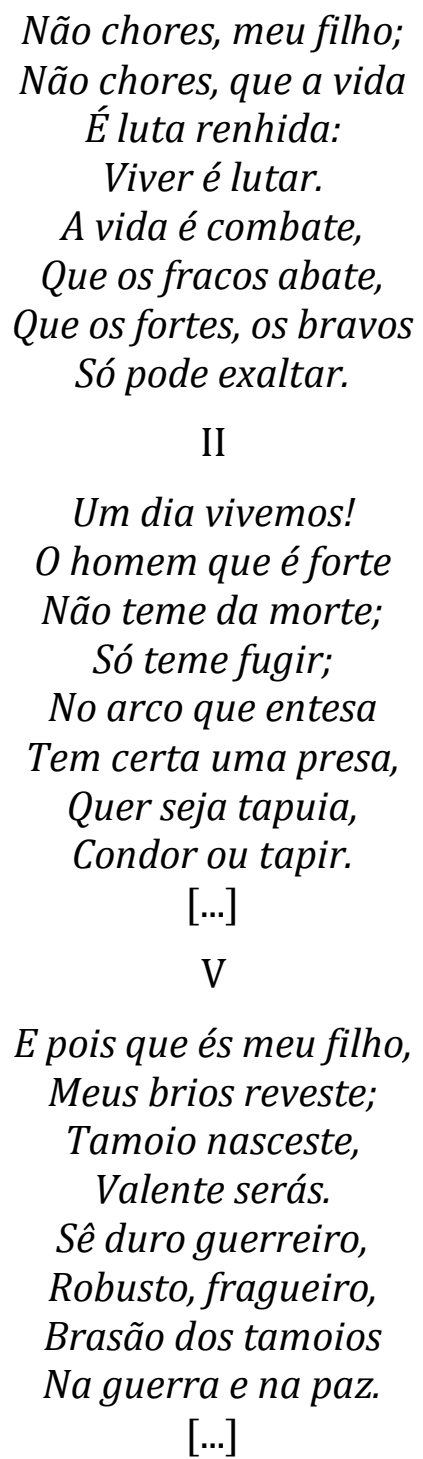

No poema A Canção do Tamoio, do poeta romântico Gonçalves Dias, o eupoético põe-se no lugar de autor como ethos indígena e compõe-se com características peculiares a um guerreio forte, lutador, destemido, valente, robusto. Ao pensarmos no modo como se discursiviza a imagem de um autor, nesse caso, da 
formação de um ethos coletivo há que se mencionar outras dimensões da ordem do discurso que definem os regimes da enunciação e compõem a autoria. Assim, o discurso se situa numa dimensão além do texto e dessa maneira possibilita que entendamos a relação entre o universo da linguagem e o universo que a extrapola, ou seja, os lugares da fala, das instituições e as condições de emergência que permitem que os discursos sejam produzidos como enunciados e acontecimento (Baronas e Bonatti, 2016). Desse modo, afirmam:

[...] um texto literário, filosófico, político ou científico não é um objeto estático: um aerólito miraculoso (para usarmos os termos de Pêcheux), ele se constitui por todo um conjunto de ritos, dentre eles estão as suas edições, as quais sofrem adaptações, constroem as demandas de leitura e exigências de determinados grupos (sociais, econômicos), em momentos distintos. Ou seja, existem dispositivos que regulam a produção e veiculação dos textos enquanto discurso (BARONAS E BONATTI, 2016, P.36).

As práticas discursivas são construídas ao longo da história da própria humanidade, seguindo certa ordem do discurso que, na análise enunciativa, denominamos por procedimentos de exclusão, ou seja, sistemas de exclusão próprios de instituições que tornam possível o discurso, aquilo que deve ser dito para a construção da verdade coletiva sincrônica e diacronicamente, como por exemplo, as interdições no que diz respeito aos elementos de poder dentro da sociedade, criando, ou outro centrado em elementos denominados num movimento opositivo de verdadeiro versus falso, a que Foucault (1996) denominou a vontade de verdade, isto é, um sistema de exclusão apoiado em um suporte institucional que, ao mesmo tempo, é reforçada e reconduzida por um conjunto de práticas sociais a que o autor chama de práticas pedagógicas, como os livros, as bibliotecas, os laboratórios, etc.

No poema, encontramos o lugar de fala de um ethos discursivo construído ao longo do processo histórico por uma política de desvozeamento do verdadeiro autor, isto é, o indígena em seu contexto de fala, e, simultaneamente, um revozeamento por aquele que o representa, o poeta, entretanto, fazendo-o como se pudesse assumir o papel de um grupo étnico e representando-o perante a sociedade, assumindo a postura de reconstrução mitológica para atribuir-se 
identidades diversas e distintas daquela que deveria ser compreendida pelo próprio discurso, qual seja, pela manifestação latente nas relações sociais reais.

\subsection{0 ethos do doce selvagem em 0 guarani por José de Alencar}

Em pé, no meio do espaço que formava a grande abóbada de árvores, encostado a um velho tronco decepado pelo raio, via-se um índio na flor da idade. Uma simples túnica de algodão, a que os indígenas chamavam aimará, apertada à cintura por uma faixa de penas escarlates, caía-lhe dos ombros até ao meio da perna, $e$ desenhava o talhe delgado e esbelto como um junco selvagem. Sobre a alvura diáfana do algodão, a sua pele, cor do cobre, brilhava com reflexos dourados; os cabelos pretos cortados rentes, a tez lisa, os olhos grandes com os cantos exteriores erguidos para a fronte; a pupila negra, móbil, cintilante; a boca forte, mas bem modelada e guarnecida de dentes alvos, davam ao rosto pouco oval a beleza inculta da graça, da força e da inteligência. ${ }^{4}$

[...]

A princípio, Peri só teve olhos para ver o que se passava dentro do aposento: Cecília examinava ainda por uma última vez as encomendas que lhe haviam chegado do Rio de Janeiro. Nessa muda contemplação, o índio esqueceu tudo. Que lhe importava o precipício que se abria a seus pés para tragá-lo ao menor movimento, $e$ sobre o qual planava num ramo fraco que vergava e se podia partir a todo o instante! Era feliz: tinha visto sua senhora; ela estava alegre, contente e satisfeita; podia ir dormir e repousar. Uma lembrança triste porem o assaltou; vendo os lindos objetos que a moça recebera, pensou que podia dar-lhe a sua vida, mas que não tinha primores como aqueles para ofertar-lhe. O pobre selvagem ergueu os olhos ao céu num assomo de desespero, como para ver se, colocado duzentos palmos acima da terra, sobre as grimpas da árvore, poderia estender a mão e colher estrelas que deitasse aos pés de Cecília. ${ }^{5}$

[...]

Uma larga fita vermelha que escapava da ferida tingia a sua alva túnica de algodão; Peri sentiu-se vacilar de repente e apertou com desespero o coração como para reter o sangue que espadanava. Foi um momento de luta terrível entre o espírito e a matéria, entre a força da vontade e o poder da natureza. O corpo desfalecia, os joelhos se dobravam, e Peri erguendo os braços como para agarrar-se à cúpula das árvores, estorcendo os músculos para manter-se em pó, lutava debalde com a fraqueza que se apoderava dele. Debateu-se um momento contra a poderosa gravitação que o vergava para a terra; mas era homem, e tinha de ceder à lei da criação. Entretanto sucumbindo o valente índio resistia sempre; e vencido parecia querer lutar ainda. Não caiu, não; quando a força lhe faltou de todo, foi-se lentamente retraindo e tocou a terra com os joelhos. ${ }^{6}$

\footnotetext{
${ }^{4}$ ALENCAR, José de. O guarani. (2018, p. 15)

5 ALENCAR, José de. O guarani. (2018, p. 35)

${ }^{6}$ ALENCAR, José de. O guarani. (2018, p. 47.)
} 
O conceito de indígena incivilizado está presente na memória discursiva e muitas vezes é reatualizado nos discursos midiáticos, reforçando a construção que a literatura fez ao longo do tempo no processo de formação da nação brasileira com os objetivos de manutenção de status quo dessa personagem que nunca foi bem compreendida por aqueles que se auto intitulam civilizados. Podemos afirmar que isso ocorre devido à presença de uma memória social que considera os indígenas selvagens, estúpidos, desprovidos de inteligência ou mesmo não humanos. Assim, ao logo do tempo, construiu-se um ethos discursivo como imagens de povos que não foram bem estudados ou descritos no processo de construção histórica do Brasil.

Para a compreensão de como se deram esses pressupostos, podemos falar em ethos retórico, de acordo com Mainguenau (1997), que ocorre quando o enunciador não possui intenções quanto aos efeitos que pretende produzir ao desempenhar o discurso; assim, esses efeitos são impostos pela formação discursiva de outrem, e não pelo próprio sujeito. Dessa maneira, esses conceitos teriam sido formados pelos interlocutores do discurso, e não pelos próprios autores. Devido à construção por meio do discurso, o ethos não é uma imagem do locutor exterior à fala, mas é uma noção discursiva, ou então, uma influência sobre o outro, ou ainda, é uma noção sociodiscursiva que não pode ser apreendida fora de uma situação precisa de comunicação.

Na teoria elaborada por Maingueneau (2013), o ethos discursivo pode ser construído de duas formas diferentes, a dita e a mostrada. A forma do ethos dito consiste em fragmentos de texto em que o enunciador evoca a sua própria enunciação e, assim, anuncia sobre ele mesmo. O ethos mostrado é construído pelo coenunciador, isto é, o destinatário do enunciado, deixado a partir dos vestígios da enunciação. Na narrativa composta por José de Alencar que descreve os dessabores da paixão do indígena Peri, descrito como "delgado, esbelto, de pele cor de cobre, de boca modelada, de beleza inculta", porém, selvagem, o ethos pode ser construído pelo próprio coenunciador, seja ele o leitor, que no decorrer da leitura da obra literária tem a oportunidade de vivenciar o grotesco amor entre a figura quase animalesca de Peri, incivilizado, inculto, selvagem, sem nenhum provento ou 
bem a oferecer à Cecília, e a bela figura da moça branca, educada, de bons modos, com refinamentos de uma aristocrata.

No decorrer processual da leitura, vai sendo construído um ethos discursivo não apenas no discurso, isto é, daquele que anuncia e escreve, mas também pelos parceiros da enunciação, quer dizer, os leitores que, ao longo do processo, vão construindo a figura imaginária do indígena brasileiro, em seu amor romântico pela mocinha, adotando o feitio de bom selvagem, transformando-o assim, numa espécie de herói em que é possível haver a miscigenação entre os caucasianos e os indígenas, embora de forma bondosa e pacificada, em que, aos poucos, o selvagem vai se transformando em uma nova imagem, considerada como mais civilizada para poder se relacionar com a bela Cecília.

Nesse contexto, o ethos de Peri se transforma no decorrer da narrativa, a princípio é o belo e selvagem, ao longo da história é fiel e resignado, no final é humano, sente dores, mesmo ferido, suporta a dor até cair de joelhos ao chão; assim, "demonstra que é homem e cede às leis da criação". A imagem construída pelo autor vai sendo legitimada pelos leitores que o aclamam e, ao final do enredo, tem-se a imagem atribuída de uma figura mitológica, por meio das construções afixadas pelos parceiros da interação, isto é, os interlocutores que precisam encontrar nos romances as razões para comportamentos apreendidos nos ideais de outrem que necessitam mobilizar experiências que justifiquem o modo de ser no mundo a que são contemporâneos.

\subsection{0 ethos do indígena cidadão brasileiro em $A$ raiva de ser índio por Daniel Munduruku}

A gente não pede para nascer, apenas nasce. Alguns nascem ricos, outros pobres; outros brancos, outros negros; uns nascem num país onde faz muito frio, outros em terras quentes; Enfim, nós não temos muita opção mesmo. O fato é que, quando a gente percebe, já nasceu.

Eu nasci índio. Mas não nasci como nascem todos os índios. Não nasci numa aldeia, rodeada de mato por todo lado. com um rio onde as pessoas pescam peixe quase com a mão de tão límpida que é a água. Não nasci dentro de uma Uk'a Munduruku. Eu nasci na cidade. Acho que dentro de um hospital. E nasci numa cidade onde a maioria das pessoas se parece com índio: Belém do Pará.

Nasci lá porque meus pais moravam lá. Meu pai é índio e viveu numa aldeia, como depois eu iria viver também. Fui o primeiro filho da família a nascer na cidade. Antes de mim já tinham nascido quatro meninas e dois meninos (um dos meninos não 
cheguei a conhecer) todos fora da cidade. Depois de mim vieram ainda três meninos. Era uma alegria só.

Meus pais tinham ido para Belém em busca de uma maneira de sustentar tantas bocas, uma vez que já não era tão fácil viver na aldeia e eles sonhavam com a cidade. Por isso meu pai aprendeu uma profissão: carpinteiro. Foi, e ainda é, um grande mestre nesse ofício.

Minhas primeiras lembranças - além de um terremoto que vivi aos quatro anos - são as de meu pai martelando, serrando e falando sobre as propriedades da madeira (acho que ele falava era do espírito das árvores só que não me lembro bem disso). De qualquer modo meu pai era um grande artesão e foi graças a essa sua habilidade que pôde sustentar tantos filhos durante tanto tempo.

Nós sempre moramos na periferia de Belém. Nossa maloca não era nossa e muitas vezes tivemos que mudar de lugar, de casa e de bairro. Foi uma época bem sofrida. Meus irmãos tivera que ir trabalhar na cidade para ajudar nas despesas. Eu mesmo fui vendedor de doces, paçoca, sacos de feira, amendoim, chopp (é um um suco colocado em saquinhos de plástico congelados. Em São Paulo chamam isso de geladinho). Fazia tudo isso com alegria. Eu era uma criança que gostava de fazer coisas novas. ${ }^{7}$

Ao construir o seu discurso o enunciador, especificamente, o ethos do indígena descrito no excerto do livro Meu vô Apolinário por um indígena da etnia Munduruku, o autor edifica para si uma imagem. De fato, não é o autor que leva à persuasão, mas a imagem criada de si por meio do ethos discursivo, de acordo com Fiorin (2017), isso ocorre quando o orador inspira confiança, assim, confiamos prontamente na imagem dos enunciadores como resultado da força do discurso. Entretanto, antes de confiar o ethos indígena do representante da etnia que nos fala, é necessário que descontruamos todas as imagens firmadas no decorrer do processo de historização e literarização da nação brasileira pelas outras vozes, ou seja, por outrem que tomaram como factual as formações discursivas que se fizeram em torno dos povos indígenas.

No excerto acima exposto, quando o autor descreve a forma que o índio é construído, discursivamente, dentro da sociedade precisa dizer que nasceu índio, mas não como as pessoas imaginam que seja a vida indígena, numa aldeia rodeada de mato por todos os lados, com rio e abundância de peixes para pescar, ou como o mito do selvagem que usa arco e flecha para guerrilhar com os inimigos Tapuias que também são indígenas - , mas como um cidadão brasileiro, dentro de uma

\footnotetext{
${ }^{7}$ MUNDURUKU, Daniel. A raiva de ser índio. In: Meu vô Apolinário. Um mergulho no Rio da (Minha) memória.
} 
organização étnica denominada Munduruku, no entanto, em uma cidade como milhares de outras existentes em nosso país. Dito isso, infere-se que o ethos é o traço de caráter que o tribuno deve mostrar ao auditório, no sentido próprio, é uma conotação que atribui confiança para o interlocutor. Quando o autor diz "eu nasci numa cidade chamada Belém" ele está ressignificando a imagem criada do guerreiro, do selvagem, do doce e serviente indígena, daquele desprovido de cultura e conhecimento, para explicitar uma nova imagem no enunciado. Ocorre uma mudança verdadeira e que dá voz a outro ethos, isto é, aquele que não necessita de outro para falar por si.

A formação do ethos, nesses termos, compreende três componentes: o caráter, quer dizer, o conjunto de características psíquicas reveladas pelo enunciador. $\mathrm{O}$ autor a que nos referimos toma para si a autoria da enunciação e posiciona-se construindo uma nova imagem do indígena que em nada difere dos outros cidadãos, passa por privações, fala da pobreza em que na fase de criança precisava vender produtos nas ruas para sobreviver, nas mudanças de casa por não ter um teto onde morar quando diz "nossa maloca não era nossa e precisamos mudar várias vezes", da profissão do pai como carpinteiro, dos irmãos que teve. Assim, autobiografa-se como integrante de uma família igual a milhares de outras existentes num país em que a desigualdade social sempre esteve presente.

O segundo componente, o corpo em que o narrador descreve suas características físicas, relatando que na cidade onde nasceu a maioria das pessoas se parece com índio, nesse caso, pele morena, estatura baixa, cabelos lisos, etc. 0 terceiro elemento na construção do ethos é o tom, ou seja, a dimensão vocal do enunciador desvelada pelo discurso. Podemos dizer que é esse tom que mexe com o auditório e que tenta mudar os estereótipos do indígena que foram se construindo ao longo do tempo para uma figura que se torna, de fato, cidadão, tanto quanto qualquer outro nascido sob a pátria brasileira, deixando de lado todas as outras formações de figuras estereotipadas construídas pela literatura brasileira.

\section{Algumas considerações}


Isso posto, há certa construção da imagem identitária dos povos indígenas que foi sendo elaborada no decorrer do processo da formação e divulgação da literatura brasileira desde o início da nação, ou melhor, a imagem do selvagem, inculto, aborígene, dentre outros adjetivos que o puseram em situação sempre inferior aos outros cidadãos brasileiros. Podemos compreender, claramente, a mobilização da construção desse ethos por mais de 500 anos de literatura em que a formação discursiva do indígena o coloca em posição minoritária e inferiorizada.

Entretanto, a imagem criada pela literatura encontra ressonância nos leitores que aceitam para si essa construção identitária porque, de algum modo, fiam-se nos elementos discursivos dos autores literários que são capazes de criar e recriar novos contextos e novos processos históricos por meio da linguagem literária. Não seria o caso de responsabilizar os literatas, mas de analisar, de fato, as relações sociais e o poder que a linguagem tem em reproduzir, construir, criar, recriar, refletir posições, destacar aquilo que é de interesse e omitir o que pode ser vergonhoso para a construção cultural de uma nação.

Poderíamos dizer, entremeios, que se trata do apagamento do ethos indígena por uma convergência entre a literatura e a história? Talvez pudéssemos dizer que o papel humanizador da literatura deve ser retomado, entretanto, em que as múltiplas vozes sociais possam ser eloquentes por meio de seus próprios representantes, mesmo quando achamos que não existe voz, que não existe linguagem ou cultura. Em tempos atuais temos um ethos discursivo com ênfase não nas vozes que dessoaram recriando uma realidade que nunca existiu, mas centrado na voz discursiva daqueles que podem falar por si e autorrepresentar-se por meio de uma nova formação discursiva, o indígena escritor literário e, sobretudo, cidadão brasileiro.

\section{Referências}

AUTHIER-REVUZ, Jacqueline. Palavras incertas. As não-coincidências do dizer. Campinas: Ed. da UNICAMP, 1998.

BARONAS, Roberto Leiser e BONATTI, Júlio. Imagens de autor de Noam Chomsky. In: BARONAS, , R. L; MESTI, P.C e CARREON, E. O. Análise do discurso. Entorno da problemática do ethos, do político e de discursos constituintes. São Paulo: Pontes, 2016. 
CANDIDO, António. 0 direito à literatura. In.: FESTER, A. C. Ribeiro e outros. Direitos humanos e literatura. São Paulo: Brasiliense, 1989.

CHARAUDEAU, Patrick. Identidade linguística, identidade cultural: uma relação paradoxal. In: LARA, G. P.; LIMBERTI, R.P. Discurso e Identidade Social. São Paulo: Contexto, 2015.

COSSON, Rildo. Letramento literário. Teoria e prática. São Paulo: Contexto, 2018.

FERRAZ, Sarah Menoya. 0 discurso constituinte e a verdade absoluta. In: BARONAS, R. L. et al. Análise do discurso: entorno da problemática do ethos, do político e de discursos constituintes. Campinas: Pontes, 2016.

FIORIN, José Luiz. Argumentação. São Paulo: Contexto, 2017.

FOUCAULT, Michel. A ordem do discurso. São Paulo: Loyola, 1996.

MAINGUENAEU, Dominique. Novas tendências em análise do discurso. Campinas: Fontes, 1997.

MAINGUENAEU, Dominique. Cenas da enunciação. São Paulo: Parábola, 2008.

MAINGUENAEU, Dominique. Ethos, cenografia, incorporação. In: AMOSSY, R. Imagens de si no discurso: a construção do ethos. São Paulo: Contexto, 2013.

MAINGUENEAU, Dominique. Discurso e análise do discurso. São Paulo: Parábola, 2015.

MAINGUENAEU, Dominique. A propósito do ethos. In. Motta, A.R. et al. Ethos Discursivo. São Paulo: Contexto, 2015.

MUNDURUKU, Daniel. Meu vô Apolinário. Um mergulho no Rio da (Minha) memória. São Paulo: Studio Nobel, 2009.

NIETZCHE, Friedrich Wilhelm. Além do bem e do mal: prelúdio a uma filosofia do futuro. Porto Alegre: R\&PM, [1900] 2008.

TODOROV, Tzvetan. A literatura em perigo. Rio de Janeiro: DIFEL, 2009.

VAN DIJK, Teun. New(s) Racism: A discourse analytical approach. In: COTTLE, S. (org.) Ethnic Minorities and the Media. Filadélfia: Open University Press, 2000.

VIEIRA, Pe. Antônio. Sermões Escolhidos. São Paulo: Martin Claret, 2011.

Outras fontes:

ALENCAR, José de. 0 guarani. Objdigital.bn.br/Acervo_Digital/Livros_eletronicos. Disponível em: http://objdigital.bn.br/ Acervo_Digital/Livros_eletronicos/o_guarani.pdf Acesso em 20/11/2018.

CAMINHA, Pero Vaz. A carta de Pero Vaz de Caminha. Biblioteca Nacional: RJ, Disponível

em: http://objdigital.bn.br/Acervo_Digital/Livros_eletronicos/carta.pdf. acesso em 20/11/2018.

DIAS, Antônio Gonçalves. Canção do Tamoio. Domínio público. Disponível em: http://dominiopublico.gov.br/acesso em 20/11/2018. 